17. Pogodin S. N. (2005). M. M. Kovalevskij. SanktPeterburg : Nestor [in Russian].

18. Pogodin S. N. (1998). Nesostoyavshijsya brak. Voprosy istorii, 3,142-146 [in Russian].

19. Rech' (1916).

20. Rosijs'kyj derzhavnyj arkhiv literatury i mystetstva, m. Moskva.
21. Rosijs'kyj derzhavnyj istorychnyj arkhiv, m. SanktPeterburh.

22. Rukopysnyj viddil Instytutu rosijs'koi literatury (Pushkyns'kyj Dim) RAN, m. Sankt-Peterburh.

23. Tsentral'nyj derzhavnyj istorychnyj arkhiv, m.Kyiv. 24. Yuzhnyj kraj (1916) [in Russian].

УДК 94 (477)

DOI $10.34142 / 2313-2345.2020 .58 .03$

Бондар Н.О.

кандидат історичних наук, доцент кафедри ЮНЕСКО «Філософія людського спілкування» та сочіально-гуманітарних дисчиилін Харківського національного технічного університету сільського господарства імені Петра Василенка ORCID: 0000-0003-3449-5884

Кошкіна O.I., кандидат історичних наук, доцент, доиент кафедри суспільно-гуманітарних наук Харківського національного університету будівництва та архітектури ORCID: 0000-0003-1123-5411

\title{
РАДЯНСЬКЕ РЕГУЛЮВАННЯ ОРГАНІЗАЦІЇ РОБОЧОЇ СИЛИ НА ПОЧАТКУ 1920-х рр.: ВІД МІЛІТАРИЗАЦІЇ ДО ВИРОБНИЧИХ АРТІЛЕЙ
}

У статті розглянуто еволючію форм організащії використання масової робочої сили у першій половині 1920-х рр. В умовах лібералізації економіки відбувалося поєднання ринкових форм організації праці з державним контролем.

У період «воєнного комунізму» однією з форм організачії трудових ресурсів були «револючійні армії праці» $i$ «трудові частини», залучення яких до роботи трунтувалося на приниипі «загальної трудової повинності». Лібералізація економіки призвела до створення на їх базі державних трудових артілей, які були об'єднані в державне акціонерне будівельне товариство “Стандарт», щэо проіснувало до травня 1927 p.

Ключові слова: трудова армія, трудові частини, трудові артілі, акиіонерні товариства.

In the context of the transition to a new economic policy, the Soviet government faced the problem of using the mass labor force. During the period of "war communism" one and its forms were "revolutionary armies of labor" and "labor units", whose involvement in work was based on the principle of "universal labor service." The liberalization of the economy required a new approach to solving the problem of using the mass labor force. This article is devoted to the study and reconstruction of this process. On the basis of previously operating paramilitary labor units, labor units were created, which were transferred to the jurisdiction of the People's Commissariat of Labor. Until December 1921, their activities were carried out in the context of ongoing labor mobilizations. To stop this practice, the Soviet government decides to disband labor units and create state labor artels on their basis, which were united into the All-Russian Association of State Workers Artels. Even in the conditions of economic liberalization, the state, creating an association, was not going to relinquish control over the use of mass labor. Therefore, in the regions, this process was perceived to formally rename labor units. To organize a mass labor force, the state is trying to attract entrepreneurs. For this purpose, the All-Russian Association of State Workers Artels is being reorganized. On its basis, a Russian joint-stock company of construction, transport, cargo and procurement works was created, the founders of which were government bodies and private individuals. However, it lasted for several months. The state did not allow private capital to exercise control over the organization of the mass labor force. In the spring and summer, the joint-stock company was reorganized into a joint-stock construction company "Standard", the shareholders of which were only state bodies, all private persons were removed from its structure. In this form it existed until May 1927. Reorganization of forms of organization and use of mass labor in the first half of the 1920s. was intense. In the conditions of economic 
liberalization, it was characterized by an attempt to combine market and socialist forms of labor organization. The experiment was not developed further. The state regained full control over the organization and distribution of the mass labor force.

Key words: new economic policy, labor army, labor artels, joint-stock companies, labor organization.

Постановка проблеми. Проблема еволюції організаційних форм трудових відносин у 1920-ті рр. в радянській державі продовжує привертати увагу істориків. Серед них немає єдиної думки про процеси організації, оплати, мотивації, фактори зміни продуктивності праці. Дискусійним залишається й питання про організацію і використання масової робочої сили в умовах лібералізації економіки.

Аналіз актуальних публікацій. Певний фактичний матеріал, що дає можливість розглянути вказану проблему, наведено в працях О. Воронянського, О. Гавриленка та В. Чеховича. Проте інтерпретація сутності та результатів реорганізації організаційних форм використання масової робочої сили в період переходу від воєнного комунізму до НЕПу різними авторами суттєво відрізняється. Так, Л. Бородкін та Є. Сафонова вважають діяльність радянських органів у сфері організації праці в період 1920-х рр. провальною. Г. Гончаров наголошує на бажанні радянської держави повністю контролювати процес використання масової робочої сили незалежно від форм іiі організації. Натомість О. Воронянський звертає увагу на аналогічність форм організації трудових ресурсів в СРСР періоду відбудови та нової економічної політики (НЕПу) та в США періоду великої депресії та Нового курсу Ф. Рузвельта.

Метою даної статті є розгляд процесу еволюції форм організації так званої «масової робочої сили» у Радянській Україні в період переходу від воєнного комунізму до нової економічної політики.

Виклад основного матеріалу. Масова робоча сила, організована в «революційні армії праці» та трудові частини, була одним із елементів організації використання трудових ресурсів період «воєнного комунізму». Громадянська війна в країні, економіка якої була виснажена Першою світовою війною,робила мобілізацію праці практичним завданням, в тому числі шляхом послідовного введення воєнного стану в ряді галузей. У міру мілітаризації госпо- дарства трудова повинність безпосередньо стала скидатися на військову. Л. Троцький, один 3 найбільш авторитетних лідерів тодішнього більшовицького керівництва, проводив лінію на повну мілітаризацію трудових відносин.

У період 1920-1921 рр. на території України діяли Українська, Донецька та Залізнична трудові армії. Рішення про створення Української трудової армії було ухвалене 21 січня 1920 р. Однак через вкрай несприятливу обстановку на фронтах іiі формування фактично було розпочато тільки в травні 1920 р. До неї були приписані запасні частини низької бойової готовності 3 різних фронтів і військових округів. 1 червня 1920 вона налічувало 20705 чоловік три трудові бригади, що включали вісім трудових полків. Частини бригад і дрібних допоміжних підрозділів Української трудової армії були зосереджені в Донбасі, а також розкидані по території Полтавської, Київської, Катеринославської та Одеської губерній. У грудні1920 р. спеціально для робіт по відновленню Донбасу з їі складу було виділено окрему Донецьку трудову армію. На початку1921 р. в Українській трудовій армії налічувалося 67 тис. червоноармійців, у Донецькій - 48 тис. А в лютому 1920 р. 3 різних армійських і тилових частин, що дислокувались у трикутнику між містами Орел, Харків і Царицин було створено Трудову залізничну армію. Ї̈̈ основним завданням було поліпшення роботи Південно-Східних залізниць і підвищення продуктивності праці по ремонту паровозів і вагонів [Чехович, 1995].

При переході до нової економічної політики формування трудових армій були в березні 1921 р передані у відання Наркомату Праці (НКП) з метою досягнення планомірності в справі постачання народного господарства робочою силою і організаційного використання всіх трудових сил, що звільняються в зв'язку з закінченням бойових дій на фронтах [Воронянський, 2012]. Вони реорганізовувалися в трудові части- 
ни, які призначалися для забезпечення робочою силою господарських органів.

У питаннях внутрішньої організації трудові частини зберігали військову структуру і військову дисципліну. У внутрішніх організаційних питаннях вони повинні були керуватися військовим статутом. Комплектувати створені трудові частини НКП планував за рахунок червоноармійців, переданих із військового відомства, а також цивільних осіб, призваних у процесі трудових мобілізацій[Гавриленко, 1999]. Як видно, навіть в умовах переходу до НЕПу радянські органи влади не відмовлялися від трудових частин як інституту організації робочої сили, змінивши лише їх підпорядкованість і зробивши акцент на залучення до них цивільного населення.

Про такий підхід до організації трудових частин говорилося в квітні 1921 року на нараді командувачів Трудармії і начальників управлінь. На ньому було сформульовано думку про їхні дії в нових умовах. Зазначалося, що найбільш раціональною та організованою формою робочої сили є трудові частини, побудовані на засадах військової дисципліни і такі, що зберігають військову структуру. Укомплектування трудових частин передбачалося шляхом вікових трудових мобілізацій [Гавриленко, 1999].

Головне управління трудових частину наказі трудовим арміям і трудовим частинам від 6 липня 1921 запропонувало зарахувати до складу трудових частин колишніх офіцерів і чиновників у порядку здійснення трудової повинності. Переписка військового відомства, Управління трудових ресурсів та Надзвичайної Комісії в період із липня по грудень 1921 р. підтверджує процес формування трудових частин на основі принципу трудової повинності [Михайлюк, 2007].

Змінити ставлення до формування i діяльності трудових частин можна було тільки ліквідувавши основу, яка їх породжувала, тобтотрудову повинність і відповідні трудові мобілізації. 12 жовтня 1921 р. Всеросійський Центральний Виконавчий Комітет (ВЦВК) наказав припинити всі оголошені мобілізації і більше їх не проводити. НКП, у свою чергу, відмовився від проведення трудових мобілізацій, а органі- зацію трудових ресурсів наказав проводити на добровільній основі. У листопаді 1921 Рада Народних Комісарів обмежила використання трудової повинності «великими стихійними лихами» [Воронянський, 2016]. Одночасно уряд проводив лінію на скорочення чисельності трудових частин: у період 31 липня по грудень 1921 р. вона скоротилася 3200 тис. чол. до 75 тис. чол. [Калініченко, 2016].

У результаті відходу від практики трудових мобілізацій розгорнулася досить широка дискусія про подальшу долю трудових частин. Було сформовано три основних напрями їх реорганізації: збереження в незмінному вигляді; перетворення на трудові артілі, що діють на основі самоокупності та добровільного формування; ліквідація трудових частин як структури, несумісної з новою економічною політикою [Михайлюк, 2007].

Край дискусіям поклала постанова Ради Праці і Оборони (РПО) від 30 грудня1921 р., відповідно до якої всі трудові частини підлягали розформуванню до 1 лютого 1922 р. Для забезпечення народного господарства робочою силою замість них створювалися трудові артілі на принципах господарського розрахунку і використання вільнонайманої праці [Калініченко, 2016]. Прибічники троцькістської лінії на мілітаризацію праці, що намагалися саботувати реалізацію даної постанови, обмежившись лише формальним перейменуванням трудових частин, у квітні 1922 р. спробували провести рішення про колективну, а не індивідуальну оплату праці робітників трудових артілей, однак навіть це їм не вдалося.

Уже із січня 1922 р. розпочалося реформування трудових частин: вони були зняті з державного постачання, всі військовозобов'язані до травня 1922 р. були демобілізовані. У листі НКП від 29 травня 1922 p. спеціально наголошувалося на тому, що оскільки «з робочих артілей весь червоноармійський елемент цілком звільнений, ... принципова постановка питання про перейменування трудчастин в трудартілі... втрачена» [ДАРФ. Ф. Р-9560. Оп. 1. Спр. 18. Арк. 132]. 
На базі трудових частин були утворені госпрозрахункові державні робочі артілі. Управління їх діяльністю здійснювалося через Всеросійське об'єднання державних робочих артілей (ВОДРА), яке замислювалося як державне об'єднання масової робочої сили, що протистоїть діяльності приватного капіталу і має за мету не «наживу», а найкращу організацію застосування масової робочої сили. Крім того, розвиток цієї нової форми організації праці мав ослабити наростаюче безробіття [ДАРФ, Ф.Р-9560. Оп. 1. Спр. 1. Арк. 1, 3, 10]. Наказ Вищої Ради народного господарства (ВРНГ) №105 від 20 березня 1922 р. рекомендував, при інших рівних умовах, надавати державним трудовим артілям перевагу перед приватними підприємцями при наданні державних замовлень [ДАРФ, Ф. Р-9560. Оп. 1. Спр. 1. Арк. 6].

У листопаді 1922 р. було здійснено подальший крок у справі переходу до економічних методів заохочення працівників. ВОДРА було ліквідовано, а його правонаступником стало Російське акціонерне товариство будівельних, транспортно-вантажних і заготівельних робіт, діяльність якого мала спиратися на ринок праці. Це товариство відносилося до типу змішаних акціонерних товариств 3 основним капіталом 1 млн. руб. золотом, при чому 29\% його основного капіталу належали приватним особам [Чехович, 1995].

Але в такому вигляді акціонерне товариство проіснувало недовго. Вже 4 березня 1923 р. РПО СРСР рекомендувала реорганізувати його в Акціонерне будівельне товариство «Стандарт». Реорганізація акціонерного товариства стала предметом обговорення на спеціально скликаній нараді 29 березня 1924 р., на якій були присутні представники державних органів (НКП СРСР, ВРНГ і Центрального управління соціального страхування) та самого акціонерного товариства. Було визнано за необхідне в якості акціонерів залучити державні органи: ВРНГ і Наркомат шляхів сполучення (НКШС). Загальні збори акціонерів АТ «Стандарт» постановили відмовитися від комерційної і лісозаготівельної діяльності та зосередити увагу на будівництві, переважно житла для робітників у великих про- мислових районах [ДАРФ. Ф. 514. Оп. 1. Спр. 1. Арк. 7; Спр. 46. Арк. 44].

Улітку 1924 р. процес реорганізації був завершений. Всі приватні акціонери зі складу товариства вийшли. На 8 серпня 1924 р. акціонерами товариства були лише державні органи: НКП, НКШС та Центральне управління соціального страхування. Відповідно до статуту товариства власники акцій не мали ніяких прав на прибуток. ВРНГ, як державний орган управління, в свою чергу, визнав необхідність надання державних замовлень на виконання будівельних робіт у першу чергу з цим товариством [ДАРФ. Ф. Р-382. Оп. 1. Спр. 76. Арк. 19; Ф. 514. Оп. 1.Спр. 1. Арк. 1-2 об.; Спр. 36. Арк. 9].

У період 1924-1927 р.p. силами трудових артілей було побудовано ряд робітничих селищ включно із соціальною інфраструктурою(передбачалося, що трудящі будуть звільнені від таких побутових проблем як приготування їжі, прання білизни, догляд за дітьми, тому будувалися загальноквартальні фабрики-кухні, пральні, дитячі ясла-садки тощо). Якість проектування i будівництва при цьому здебільшого була досить високою. Наприклад, котеджі та багатоповерхові будинки селища залізничників «Червоний Жовтень», які до сьогодні збереглися в Харкові на Лисій горі, вражають як надійністю конструкції , так і її ергономічністю.

Разом із тим, відмова від отримання прибутку призвела до того, що переважна більшість структурних підрозділів АТ «Стандарт» були збитковими, оскільки бралися за виконання хоча й соціально значущих, однак збиткових робіт. Усього із 17 агентств і відділень товариства прибутковими виявилися тільки два. У 1927 р. АТ «Стандарт» було ліквідовано [ДАРФ. Ф. 514. Оп. 1. Спр. 1. Арк. 22 об.; Спр. 46. Арк. 44-46 об.; Спр. 60. Арк. 64].

Висновки. Таким чином, у першій половині 1920-х рр. еволюція форм організації та використання масової робочої сили була досить динамічною, пройшовши шлях від мілітаризації в період воєнного комунізму до госпрозрахункових трудових державних артілей у період НЕПу. В умовах лібералізації економіки вона характеризува- 
лася спробою поєднати ринкові форми організації праці 3 державним контролем. Пошук оптимальних організаційних форм носив експериментальний характер. Однак, незважаючи на це,їх використання дозво-

\section{ЛIТЕРАТУРА}

1. Воронянський О. В. Економічна політика держави в сучасній Україні: короткий огляд // Гілея. Вип. 2012. Т. 59. Київ, 2012. С. 692-697.

2. Воронянський О. В. Неоконсервативна модель державного регулювання економічних процесів: сутність та досвід // Вісник Харківського національного технічного університету сільського господарства. Вип. 177 «Економічні науки». 2016. С. 51-60.

3. Гавриленко О. А. Правова політика радянської влади щодо українського селянства у перші роки лило досить швидко пройти період відновлення економічної інфраструктури, що прийшла в занепаду результаті майже семи років військових дій.

НЕПу // Вестник Международного славянского университета. 1999. Т. 2. № 1. С. 44-50.

4. Державний архів Російської Федерації (ДАРФ).

5. Калініченко В. В. и др. Історія України: від найдавніших часів до сьогодення. 2016.

6. Михайлюк А. В. Революция в России // Колізії синтезу філософії і релігії в історії вітчизняної філософії (до 180-річчя). 2007.

7. Чехович В. А., Зайцев Л. О. Проблеми національно-державного будівництва України в роки непу. Харків, 1995.

\section{REFERENCES}

1. Voronianskyi, O. V. (2012). Ekonomichna polityka derzhavy v suchasniy Ukrayini: korotkyy ohlyad. [Economic policy of the state in modern Ukraine: a brief overview] Hileya. Kyiv.Vyp 59, 692-697. [Gileya.Kyiv, 2012. Issue, 59, 692-697] [in Ukrainian].

2. Voronianskyi, O. V. (2016). Neokonservatyvna model' derzhavnoho rehulyuvannya ekonomichnykh protsesiv: sutnist' ta dosvid. [Neoconservative model of state regulation of economic processes: essence and experience]. Visnyk Kharkivs'koho natsional'noho tekhnichnoho universytetu sil's'koho hospodarstva, 177 «Ekonomichni nauky», 51-60. [Bulletin of Kharkiv National Technical University of Agriculture, 177 «Economic Sciences». 2016, 51-60] [in Ukrainian].

3. Havrylenko, O. A. (1999). Pravova polityka radyans'koyi vlady shchodo ukrayins'koho selyanstva u pershi roky NEPu. [Legal policy of the Soviet government towards the Ukrainian peasantry in the first years of the NEP.] Vestnyk Mezhdunarodnoho slavyanskoho unyversyteta, 2(1), 44-50. [Bulletin of the International Slavic University, 2 (1), 44-50] [in Ukrainian].

4. Derzhavnyy arkhiv Rosiys'koyi Federatsiyi [State Archives of the Russian Federation][in Russian ].

5. Kalinichenko, V. V., \&Voronianskyi, O. V. (2016). Istoriya Ukrayiny: vid naydavnishykh chasiv do s'ohodennya.[History of Ukraine: from ancient times to the present] [in Ukrainian].

6. Mykhaylyuk, A. V. (2007). Revolyutsyya v Rossyy. [Revolution in Russia.] Koliziyi syntezu filosofiyi i relihiyi $\mathrm{v}$ istoriyi vitchyznyanoyi filosofiyi (do 180richchya.[Collisions of the synthesis of philosophy and religion in the history of national philosophy (to the 180th anniversary] [in Ukrainian].

7. Chekhovych, V. A., \& Zaytsev, L. O. (1995). Problemy natsional'no-derzhavnoho budivnytstva Ukrayiny $\mathrm{v}$ roky nepu.[Problems of nation-building of Ukraine in the years of the NEP] [in Ukrainian].

кандидат історичних наук, доцент, провідний науковий співробітник лінгвістичного науково-дослідного управління Військового інституту Київського начіонального університету імені Тараса Шевченко ORCID ID:http://orcid.org/0000-0002-3739-3624

\section{КИїВСЬКИЙ ВІЙСЬКОВИЙ ОКРУГ У 1862 - 1914 РОКАХ}

У статті досліджуються основні фактори створення та аналізуються головні етапи становлення та розвитку Київського військового округу протягом 1864-1914 років. Основна увага приділяється вивченню місия та ролі всіх тих прочесів, щзо відбувалися в Київському військовому округу в межах модернізаиії збройних сил Російської імперії. Результати Кримської війни не залишили в російському суспільстві сумнівів в необхідності проведення військової реформи. У статті аналізується процес створення в краӥні військово-окружної системи, розглядаються досягнення та недоліки переозброєння армії, вдосконалення систем бойової підготовки військ, реформування комплектування армійських частин, реорганізацію системи військової освіти, иляхи та масштаби підготовки офіцерських кадрів тощо. Доводиться, що армія в Російській імперії займала особливе місие й була уні- 